\title{
樆 \\ First report of Hosta virus $X$ infecting Hosta in the Czech Republic
}

\author{
A. Koláčková*, I. Gafránková and L. Holková
}

Department of Crop Science, Breeding and Plant Medicine, Mendel University in Brno, Zemědělská 1, 61300 Brno, Czech Republic

*E-mail: xbradaco@node.mendelu.cz

Received: 26 Mar 2011. Published: 07 Sep 2011. Keywords: HVX, RT-PCR

Hostas (Hosta spp.) are popular herbaceous perennial plants represented by over 7000 varieties, and widely cultivated due to their diversity in leaf shape and colour patterns, shade tolerance and pest resistance. In the Czech Republic, hostas are grown as outdoor ornamental plants. At least four viruses in hosta have been reported in the world, but Hosta virus $X$ (HVX) is the most economically important virus infecting hostas (Ryu et al., 2006). HVX is a member of genus Potexvirus (family Flexiviridae), and was first identified and described in Minnesota, USA in 1996 (Currier \&Lockhart, 1996). Since then, HVX was reported in hosta in Tennessee and Ohio, USA (Fajolu et al., 2009; De la Torre, 2009) and from Korea and Poland (Park \& Ryu, 2003; Cajza \& Zielińska, 2007). Leaves infected with HVX commonly show symptoms of mosaic, mottling, interveinal chlorosis between secondary veins and leaf desiccation, and deformation. Infected plants often exhibit reduced growth and dieback. HVX can be transmitted from infected to healthy plants by cutting practices used for propagation and breeding, as well as in HVX-contaminated soils (Ryu et al. 2006).

During 2010, a total of twenty five hosta plants of five different species and twenty different cultivars showing various virus-like symptoms including mosaic, mottling (Fig. 1), leaf chlorosis and leaf distortion were collected from six locations throughout the Czech Republic. Presence of HVX was also tested on plants without symptoms, but occurrence of HVX was not detected in these plants. Plants were mostly obtained from the collection of hosta cultivars at Lednice (Faculty of Horticulture, Mendel University Brno), Botanical Garden and Arboretum (Mendel University Brno), horticulture in Prague, and gardens in Brno. Other samples were purchased at garden centres in South Moravia and Central Bohemia. Tota RNA was isolated from $100 \mathrm{mg}$ of fresh leaf tissue from all hosta plants collected using the RNeasy Plant Mini Kit (Qiagen, Germany). The presence of HVX was confirmed by RT-PCR using a specific primer pair PHVXCP5 and PHVXCP3 that amplifies the HVX coat protein $(\mathrm{CP})$ gene (Park \& Ryu, 2003). HVX amplification products of the expected size $(663 \mathrm{bp})$ were obtained for 19 out of 25 hosta plants analysed.

Seven isolates of HVX were sequenced and resulting sequences were aligned and showed nucleotide identities ranging from 99 to $100 \%$, when compared with each other. BLAST analysis yielded identities from 98 to $100 \%$ when HVX sequences were compared with those available in GenBank (HVX-Kr, Accession No. AJ620114 and HVX-U, AJ517352). Comparison of deduced amino acid sequence of CP gene from all the Czech isolates and HVX-Kr and HVX-U showed identities from 99 to
$100 \%$. The nucleotide sequence data of CP genes reported in this article have been deposited in GenBank under Accession Nos. JF301948-JF301954. In Europe, HVX has been previously reported only from Poland (Cajza \& Zielińska, 2007). Therefore this is the first report of the occurrence of HVX in the Czech Republic. HVX is easily mechanically transmitted and can survive in the infected plants without showing symptoms for years. More than 56 hosta cultivars have been found to be susceptible to this virus in USA (De la Torre, 2009). To minimise HVX spread, the planting of HVX-free hostas and destroying of HVX-infected plants are recommended. The combination of RT-PCR and sequencing proved the best approach for a reliable and specific diagnostic of HVX in the Czech Republic.

\section{Acknowledgements}

This project was supported by IGA AF MENDELU Brno No. IP 6/2010 and IGA AF MENDELU BRNO No. TP 4/2010.

\section{References}

Cajza M, Zielińska, L, 2007. Hosta virus $X$ - A new pathogen of ornamental plants in Poland. Progress in Plant Protection 47, 69-72.

Cajza M, Zielińska, L, 2007. Hosta virus $X$ - A new pathogen of ornamental plants in Poland. Progress in Plant Protection 47, 69-72. [doi:10.1094/PD-80-1040]

De la Torre CM, 2009. Molecular characterization, differential movemen and construction of infectious cDNA clones of an Ohio isolate of Hosta virus $X$. Ohio, USA: Ohio State University, $\mathrm{PhD}$ thesis.

De la Torre CM, 2009. Molecular characterization, differential movement and construction of infectious cDNA clones of an Ohio isolate of Hosta virus $X$. Ohio, USA: Ohio State University, $\mathrm{PhD}$ thesis.

[doi:10.1007/s00705-009-0522-6]

Park MH, Ryu KH, 2003. Molecular evidence supporting the classification of Hosta virus $X$ as a distinct species of the genus Potexvirus. Achives of Virology 148, 2039-2045. [doi:10.1007/s00705-003-0154-1]

Ryu KH, Park MH, Lee MY, Lee JS, 2006. Characterization and seed transmission of Hosta virus $\mathrm{X}$ isolated from Hosta plants. Acta Horticulturae 722, 91-93.

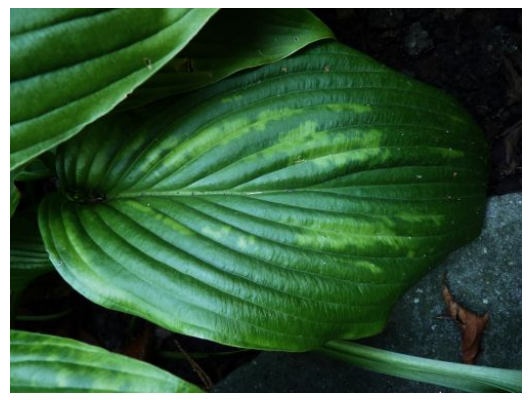

To cite this report: Koláčková A, Dafránková I, Holková L, 2011. First report of Hosta virus X infecting Hosta in the Czech Republic. New Disease Reports 24, 9. [doi:10.5197/j.2044-0588.2011.024.009] 